\title{
General Budget Deficit Financing Model in Third World Country
}

\author{
Dr. Abdullah Ibrahim Nazal \\ Department of Finance and Banking, Faculty of Economics and Administrative Sciences, \\ Zarqa University, Jordan \\ E-mail: nazzalacademy@yahoo.com
}

Received: January 23, 2014 Accepted: May 20, 2014 Published: July 5, 2014

doi:10.5296/jsss.v1i2.5919 URL: http://dx.doi.org/10.5296/jsss.v1i2.5919

\begin{abstract}
This study concentrates on financing general budget by deficit in third world country. It declared deficit reasons, dealing types and explained about 19 ways of financing budget with comparing in order to show choices. As result to study, success of any solution must be suitable to country environment limits. Searcher recommended finding suitable model from this search tables to compare with choices and limit choosing budget finance up to country environment and balancing between government needs, companies needs and citizen needs.
\end{abstract}

Keywords: General budget deficit, Finance model, Environment, Citizens, Companies and Government 


\section{Introduction}

\subsection{Background}

Deficit mean expenses are more than return. Budgets in advanced economics have most often been in deficit and economic commentators use the absolute size of budget deficit measured as a proportion of gross domestic product (Makin, 2002) Deficit means problem if it leads to reduce domestic gross product as standard show weakness of covering local needs by local efforts. There must be experts of choosing way of managing general budget by deficit up to savings needs, investing needs and daily dealing needs whether for government, companies, citizen and public ownership. They must understand country environment, available resources and solutions ways.

Many economists argue that growing budget deficits cause current account deficit. This proposed relationship between the fiscal and external deficits is often referred to as twin hypothesis. The possible causal links between the budget deficit and the current account deficit can be analyzed using saving and investment framework. Higher budget deficit affects on domestic saving and investment behavior and hence the economy international borrowing requirement (Makin, 2002). Jordan is case study applied correcting structural imbalances. It decided in 1997 to gradual reduction in the budget deficit to gross domestic product ratio excluding grand to no more than $3 \%$ also elimination of balance of payments current account deficit and reduction of external debt to gross domestic product ratio to a level not exceeding $100 \%$. It decided to maintenance of annual rate of inflation at $4 \%$ to $5 \%$ and reduction of external debt services as percentage of exports of goods and services to a level not exceeding $25 \%$ (Jordan ministry of planning, 1994). In spite of this plan it facing now debts problems and reducing of local companies' value.

\subsection{Problem}

Jordan as case study faces problem of increasing its loans to be near to it gross domestic product in current price in 2014 . It needs solution.

This search problem concentrates on country faces a limit resources revenue and obligatory current expenses to cover its employments salary and support poor or limit income citizen to cover their needs. Its general budget structure financing by tax and loan with bad gross domestic products because tax too high comparing with other countries and country services for investing is costly. It reduces domestic companies and citizens investment. It increases import to cover needs and increase inflation.

This means: financing by loan is delay problem not solving problem. The problem questions are:

1- What are budget deficit dealing types?

2- What are the limits to apply financing general budget by loan?

3- What are the choices to finance general budget without loan?

4- Is there a model show budget financing choices in comparing way to help government?

\subsection{Importance}

Because there in no one model to rule all deficit case as result to different environment, This search gives idea about managing general budget in deficit case. It organizes decisions 
practically and avoids ignorance to build trust. It gives model as way to choose solutions and discussing affection before applies also added needs to apply perfectly. It helps to unit citizen, companies and government efforts as result to understand solutions importance to solve their problems to gather.

\subsection{Limits}

There are limits to finance budget by deficit as follow:

1- Financing general budget by deficit must avoid choosing solution as result to quick case without understand positive and negative affection of choosing or weakness control or weakness experiences or weakness understanding from government employees or companies and weakness fighting immoral leader.

2-There must be closure. Ignorance may be caused, Ex: Some economists consider assets selling as assets inflation because there is no real investing return. It uses to increase gross domestic products in case of depression statistically (Manmohan, 2014).

3- There is a role for government involvement in economy because of bad affect on market system automatically functions. Government involvement must be perfect in imperfect market (Hendrik, 2001).

\subsection{Objectives}

It aims to find general budget deficit solutions and organize these solutions up to classifications in order to choose suitable solution up to country environment limits as follow:

1- To discuss Country general budget deficit case dealing types.

2- To discuss general budget financing choices by showing positive and negative affection of choosing.

3- To rule choosing solution up to balancing between government needs, companies' needs and citizen needs to apply solution.

\subsection{Studies Related to the Search}

Financing budget with deficit has good effect and bad effect therefore studies try to solve problem up to environment. (Mashaqbah, 2003) aimed to analysis general budget deficit in Jordan up to correcting economic policy. He found that reducing of current expenses and obligate price on essential products produced by local company and increase tax beside courage foreign companies was not succeeded to restructure because of increasing deficit and loosing middle type of income level. (Peter, 2010) explained Liquidity and money position managers choose their source of liquidity based on several key factors, including immediacy of need, duration of need, market access, relative cost and risks, the out for market interest rate, the outlook for central bank monetary policy and government regulations therefore budget financing by deficit can direct companies and help to finance its assets in suitable way.

\section{Deficit Case Dealing Types}

Deficit may become temporary. There are three ways to face temporary deficit. Country can get in self sufficient or surrender to economic equilibrium law or delay problems. Every way has positive affections and negative affections therefore government must apply rules to control positive affect and face negative affect. Ways of facing deficit has affection on local 
markets. It may success or get in problem of ignorance as result to many adjusting or many changes of every adjusting. It makes environment complex which loss rule of economic equilibrium. Companies can not expect risk. It will be against stability and loss trust.

Deficit may become permanently. Country faces problems as immigration of capitals, expert human resources, creditors, companies and trust on other hand country cause deliberate deficit by finance general budget by loan. Government thinks managing general budget by deficit now will increase return or solve liquidity problem as follow:

1- Country avoids expect increasing of future capitalized resource price.

2- It avoids delay covering of citizens needs as result to limit resources or foreign monopolized on product or as power of controlling foreign market.

3- To face unusual problems as earthquake.

4- Some ideas courage to finance by deficit as way to push liquidity in order to increase investing. Companies can get loan to increase producing and get reputation also citizens can get loan to buy investing tools as shares or buy direct producing assets as industry machines. Some idea of government pushing liquidity is to increase consumption by increase employments salary or give aids. This increase demand on products to courage companies producing.

5- Pushing liquidity can direct market to reduce selling by credit and reduce creating money. Reduce dealing with credit discount or delaying will reduce investor liquidity problems and courts routines.

Any solution will affect on companies and citizens. Ex: Private companies decide their cash holding policies and dividend payment up to market expectation, if country increase expenses amount as aids to people, this courage company to get payments in cash more than delay. Increasing of expenses for government employee in some countries as USA will increase insurance return, financial market dealing and increase daily dealing to courage producing (Jean, Thomas, Jean, \& Stephane, 2011).

\subsection{Get in Self Sufficient}

It mean to cover citizens needs by local producing ways or cover all citizen needs by increasing export than import as result to producing strategy product which can be bought in international markets with suitable price to buy international product which cover all citizen needs as Oil.

There are conditions to get in self sufficient. It is different from country to other as result to resources cost and experiences of managing human resources, land and capital perfectly. Conditions are as follow:

1- There must be companies which has real experience in local studies of using resources perfectly to find the suitable product to be produced in low cost than international producing. Some countries have oil but other has sciences technique as result to human experiences while other has agriculture product. It depends on reducing cost than international markets.

2- Find human experiences to managing capital and lands perfectly up to country environment. These experiences can be brought by courage foreign experiences to come to country also by build local experiences from school to university or to send citizens to get 
experiences from other countries. Experiences can solve usual problems and unusual problems with suitable ways which reduce cost.

3- To change citizen behavior to be producer. Some countries schools teach pupils to repair home electrical machines and produce agriculture products from their home. Country courage schools to make farms in schools. Student in university must get practically case studies with theoretical studies to reduce training cost in work market.

4- Country leaders must have strategy to get in self sufficient.

5- Reduce competition between local companies and international companies to make locally producing profitable.

6- There must be restructuring of financing distributing, investing distributing and managing organizing.

7- There must be rule to cover emergency needs be for other needs.

8- There must be fixed suitable ways of evaluating. It must evaluate assets value with profit to avoid ignorance. Company may have suitable net profit after tax but it loss assets value. This mean the standard is (profit from sales + increasing of assets value or - reducing of assets value). There must be suitable evaluated for cost. Ex: Costs of getting ISO quality certification must apply quality on product to deserve increasing of price not deserve increasing of price because of ISO promotion. There must be evaluating of organization added value to economic. Ex: insurance company must protect citizens and companies practically. If citizens and companies buy its services to feel safety there will be reducing of their savings so government may change insurance from profit companies to be sharing in public box or make sharing between sharers to avoid risk by their saving box to make saving reduce up to real loss.

These conditions will direct ways of financing general budget by deficit. There will be different expenses or added other expenses. Reducing cost of producing by time is the law. Applying this way may increase deficit as result to building cost increasing but there must be limit time until cost decreased to reach self sufficient. It needs trust and cooperation between government, companies and citizen. It may apply programs to make citizen producer up to resources of producing types.

\subsection{Surrender to Economic Equilibrium Law}

Supply and demand are the law to lead economic. When demand increase companies must increase producing to face covering needs until it cover all needs. Increasing supply will cover needs until it get in satisfaction then its price will reduce and other demand increase to direct supply to cover. This supply and demand are rule of economic equilibrium. The problem is country can not apply this rule on all product as result to loss self sufficient there fore it gets import. Apply this rule must be arranged up to country producing ability or it face of import expenses increasing.

Surrender to economic equilibrium law is mean to limit government financial policy and monetary policy. Government will be the ruler to apply law not to be investor or supplier. Law must avoid ignorance, unfairness and deceiving which lead to conflict. This case can be way to compete self sufficient. 


\subsection{Delay Problems of Financing General Budget by Deficit}

General budget shows country expenses and ways of face these expenses by returns. Government can delay buying its liabilities by get time and increase interest. This means to face loan by other loan. Delay buying loan may be covered in future or it may be lead to other deficit. Loan types explain that government can get loan directly from local banks or international banks and it can get loan by selling bond in local financial market or international financial markets. But the reason of getting loan must solve country problem. If it not leads to solution it mean country will loss in future. See types of loan ways developing in next table:

Table 1. Comparing between loan ways

\begin{tabular}{|c|c|c|}
\hline Loan ways & Disadvantage & Advantages \\
\hline 1- Get international loan & $\begin{array}{l}\text { High risk when country currency } \\
\text { rate became weak. }\end{array}$ & \\
\hline 2- Get domestic loan & $\begin{array}{l}\text { Loose people trust if crisis has } \\
\text { not solved. }\end{array}$ & \\
\hline $\begin{array}{l}\text { 3- Buy international goods in } \\
\text { installment and delayed }\end{array}$ & $\begin{array}{l}\text { High risk when country currency } \\
\text { rate became weak it increase loan } \\
\text { amount in local currency to } \\
\text { change to foreign country } \\
\text { currency. }\end{array}$ & $\begin{array}{l}\text { It helps to increase financing } \\
\text { investment or finance expenses as } \\
\text { way to delay budget government } \\
\text { liabilities. }\end{array}$ \\
\hline 4- Sell Bonds & $\begin{array}{l}\text { It increase interest or decrease up } \\
\text { to credit classification type } \\
\text { reducing. }\end{array}$ & \\
\hline
\end{tabular}

\section{Tools Choices to Financing General Budget}

Every country has different environment. Regardless of difference environments, Choosing solution must by ruled by covering needs of companies, citizens and government it must maximum tool positive affection and minimize tool affection in order to be fairly choosing. As result to explain loan affection there are other tools to finance budget as tax returns, social insurance savings and other types. Every way of financing budget must be clear by definition. Definition makes easier to measure the factors influence on process performance of budget items. Definition makes easier to analyze the item performance, improve item up to the possible solutions and control item up to standardize to minimize chances for error (Peter \& Jan, 2005).

3.1 Tax Types: as sales tax, tax on profit after interest, tax on operation profit, tax on tax, customs tax and income tax. This way of finance means more loss of citizen savings or investment returns. See next table: 
Table 2. Affection of financing general budget by tax types

\begin{tabular}{ll}
\hline Affection & Tax Types \\
\hline Sales tax & $\begin{array}{l}\text { Reduce citizen savings as result to buy sales. Sales tax on some products } \\
\text { may direct citizen to avoid buy this product but if it on necessary product } \\
\text { for emergency needs and every citizen have to buy this mean loss of } \\
\text { currency power of buying in the country. This leads to increasing prices } \\
\text { as causing intended inflation in future. This way mean to finance deficit } \\
\text { locally without reduce currency power buying in international markets. } \\
\text { Reduce citizen savings as result to reduce citizen investment return but } \\
\text { reducing is less than tax on operation profit because it gives financial } \\
\text { leverage as result to increase producing by loan and interest is considers } \\
\text { as expenses reduce tax. } \\
\text { Reduce citizen savings as result to reduce citizen investment return } \\
\text { regardless of interest cost of financing by loan. } \\
\text { Rax on operation profit } \\
\text { Rax on tax } \\
\text { increase to face increasing of citizen investment return. } \\
\text { Reduce citizen savings as result to reduce citizen investment return up to } \\
\text { conditions of income amount. It increases to face increasing of citizen } \\
\text { investment return but it can be faced by sharing in companies without } \\
\text { distribute returns to keep assets increasing. }\end{array}$ \\
\hline
\end{tabular}

Tax needs rules to control collecting. Rules must show who must buy tax and its amount. It must show way of tax calculating practically to avoid ignorance which leads to conflict with government. Ex: income tax must apply on distributed net profit after tax regardless of assets value reducing which will reduce tax in future.

\subsection{Citizens Social Insurance}

Apply obligated insurance as way to collect savings until get retire. Government can get part of these savings depending on obligated order to be bought by every citizen and citizen will not get these savings until spend years in future. At time of citizen retire there will be many citizens buy this insurance for many years. See next Table: 


\begin{tabular}{|c|c|c|c|c|c|c|}
\hline \multicolumn{7}{|c|}{10 groups $\times 1000000$ as result to added new sharer group in 2009} \\
\hline \multicolumn{7}{|c|}{9 groups $\times 1000000$ as result to added new sharer group in 2008} \\
\hline \multicolumn{7}{|c|}{8 groups $\times 1000000$ as result to added new sharer group in 2007} \\
\hline \multicolumn{7}{|c|}{7 groups $\times 1000000$ as result to added new sharer group in 2006} \\
\hline \multicolumn{7}{|c|}{6 groups $\times 1000000$ as result to added new sharer group in 2005} \\
\hline \multicolumn{7}{|c|}{5 groups $\times 1000000$ as result to added new sharer group in 2004} \\
\hline $\begin{array}{l}\text { suppose in forth year of } \\
\text { building social insurance box } \\
\text { there were } 1000 \text { person every } \\
\text { person buy } 1000 \text { every year this } \\
\text { mean this year box contain } \\
1000000 \text { which share in }(2000)\end{array}$ & \multicolumn{3}{|c|}{$\begin{array}{l}\text { Added last sharers, there were } \\
1000 \text { person every person buy } \\
1000 \text { every year this mean this } \\
\text { year box contain } 1000000 \text { which } \\
\text { share in }(2001)\end{array}$} & \multicolumn{2}{|c|}{$\begin{array}{l}\text { Added last sharers, there were } 1000 \\
\text { person every person buy } 1000 \text { every year } \\
\text { this mean this year box contain } 1000000 \\
\text { which share in (2002) }\end{array}$} & $\begin{array}{l}\text { Added new sharers, } \\
\text { there are } 1000 \\
\text { person every person } \\
\text { buy } 1000 \text { every year } \\
\text { this mean this year } \\
\text { box contain } \\
1000000 \text { which } \\
\text { share in }(2003)\end{array}$ \\
\hline \multicolumn{2}{|c|}{$\begin{array}{l}\text { suppose in third year of building social } \\
\text { insurance box there were } 1000 \text { person } \\
\text { every person buy } 1000 \text { every year this } \\
\text { mean this year box contain } 1000000 \\
\text { which share in }(2000)\end{array}$} & \multicolumn{3}{|c|}{$\begin{array}{l}\text { Added last sharers, there were } 1000 \\
\text { person every person buy } 1000 \text { every year } \\
\text { this mean this year box contain } 1000000 \\
\text { which share in (2001) }\end{array}$} & \multicolumn{2}{|c|}{$\begin{array}{l}\text { Added new sharers, there are } 1000 \text { person every } \\
\text { person buy } 1000 \text { every year this mean this year } \\
\text { box contain } 1000000 \text { which share in (2002) }\end{array}$} \\
\hline \multicolumn{3}{|c|}{$\begin{array}{l}\text { suppose in second year of building social insurance box there } \\
\text { were } 1000 \text { person every person buy } 1000 \text { every year this mean } \\
\text { this year box contain } 1000000 \text { which share in }(2000)\end{array}$} & \multicolumn{4}{|c|}{$\begin{array}{l}\text { Added new sharers, there are } 1000 \text { person every person buy } 1000 \text { every } \\
\text { year this mean this year box contain } 1000000 \text { which share in (2001) }\end{array}$} \\
\hline \multicolumn{7}{|c|}{$\begin{array}{l}\text { Suppose in first year of building social insurance box in (2000) there were } 1000 \text { person every person buy } 1000 \text { every year this mean this } \\
\text { year box contain } 1000000\end{array}$} \\
\hline
\end{tabular}

Figure 1. Citizens social insurance saving in 2000 finance general budget

This table shows citizens social insurance saving in 2000 finance general budget. Suppose general budget get 1000000 in 2000 and retire time for this group will be after 10 year. 1000000 will be after 10 years $=10000000$ in the box. It finances by new sharer even government do not buy credit.

\subsection{Reduce Local Currency Power of Buying}

It come as result to cause inflation locally on all goods and services or makes its power reduce by monetary policy order by government. Government can reduce its currency portfolio to which supports its currency power of buying. This means to loss cash savings up to reducing power of buying. It courage international companies to make investment in case it lead to reduce human resources cost or raw material cost. It can produce product in cheap cost to sell in high price in international market. It will increase loosing of local savings and investment also future investing by social insurance will be lost it power of buying. Poor people will be increased to increase general budget expenses. Local companies will need time to solve its loss. It may increase export rather than covering domestic needs because of loosing buyers.

\subsection{Other Financing Tools to Finance General Budget in Deficit Case}

There are many ways as tax and social insurance savings which can reduce tax negative affection and save using of social insurance saving in case of government get in loose or avoid savings loosing in case of reduce local currency power of buying. See net table: 
Table 3. Choices tools of financing general budget

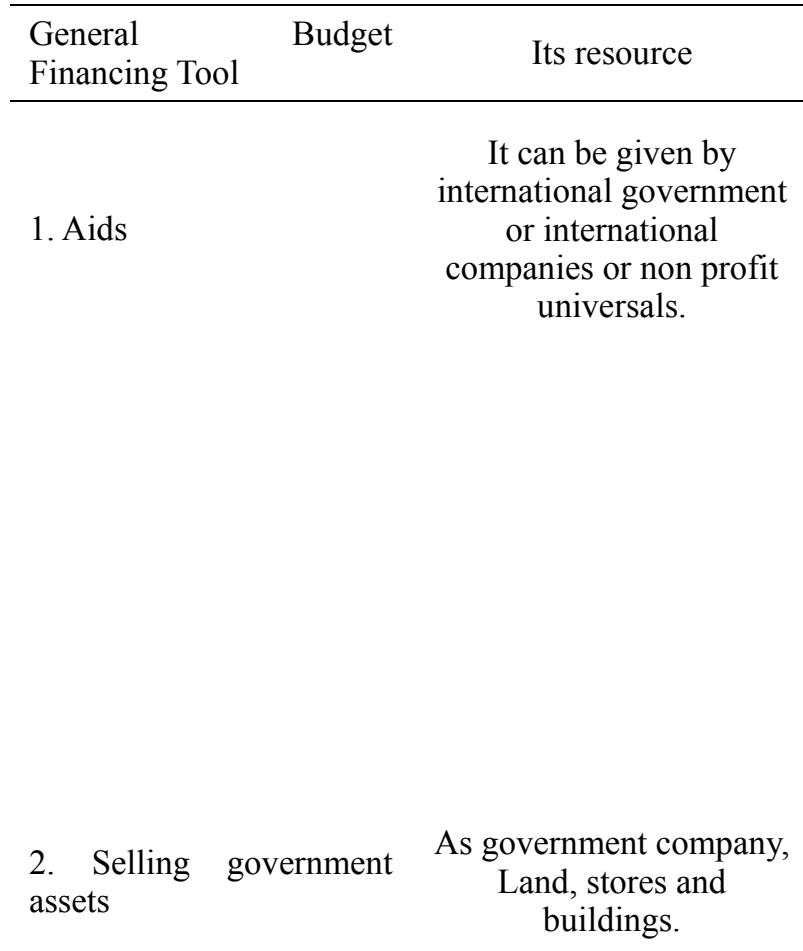

\section{assets}

\section{Reduce import cost}

4. Government

investment

4.1 Find new resource of return

Find other suppliers with less cost or give orders to decrease import amount of some goods which not necessary or depend on local companies to cover some needs by courage local investment.

It may make investment locally or internationally in other country.

As finding new material by drilling to be sold in international markets or teaching technical increase private investing. programs to export human experts resources as way to get their

Positive Affection
It increases general
budget revenue freely

It increases general budget revenue. There is possibility to courage

It courage's domestic investment and reduce affect of tax negative affect

Negative Affection

The problems are coming from applying difficult conditions

to get aids or giving promise without giving aids

It reduce government ownership amount. It may case statically increasing of gross domestic product with out add value to ignore its economic growth. It may lead to inflation in limit producing countries. It may lead to loss power of controlling as selling the only electrical stations in the country which make buyer apple to get power of monopolization to distribute electrical services and increasing price. Selling mean to loss future government returns of electrical station even it depend on its tax there is way to be reduced as result monopolization power or ways of reducing tax by financial developing tools.

It may reduce relationships with some countries as way to protect its export products selling.

This investment can cover local needs by products or by foreign currency to finance import or transfer local employees as result to find new jobs.

when it success it will be profitability
It will be costly in first step of applying and need time. 
4.2 Sharing with companies and citizens

4.3 Cooperating with other country as way to make integration

4.4 Courage international investment in the country

5. Use Citizens savings in local banks

uses part of current account in its local banks

as result to keeping savings in country center bank.

Every country has good relationship and can add value to economic sectors or cover domestic need with suitable cost.

6. Transfer expenses to companies which apply obligated insurance types
Insurance companies grantee
Increasing income to increase country returns

Get loan by local resources in order to reduce inflation and with suitable cost to government as result to law which consider current account in bank as loan without interest.

It transfer risk from general budget to these companies. It reduces

It helps to get tax and with suitable cost and reduce import amount currency

It increases producing in country if it can complete produce products which increase its local market ability to cover domestic needs in suitable cost and to producing ability grant to harmless people whom get in elder age, accident, illness and death family cost. Also
It may fight domestic companies as big competitor. It needs time and organization condition to success neither than tax which need less effort.

Weakness of local producing come as result transfer expert human resources, producing resources and capital.

"When the country decides to courage Public- Private partnerships and marketing for expected projects, there is fact that Sellers reject projects if they do not recognize its value. Therefore recognizing affects assets acceptability or liquidity" (Benjamine, Andrew and Randall, 2011: p. 356)

Controlling aims against country and Decrease returns by transfer profit to other country. "If the plan is marketing

international, the increase in international competition produce effect that reduces domestic profits and income" (Giammario, 2010: p. 1152).

It may face citizen increasing order to get unaccepted amount of there current account as by increasing dealing of checks or debt electronic cards. Country may face difficult and order banks to limit amount or time of getting savings. This way of financing will get in depression as result to loss liquidity in markets.

It increase cost on citizens and reduce current savings. Also

insurance may be limit to cover risks because insurance company looking for profit. 
7. Reducing cost of government owning by lease

\section{Charity and Zakat}

9. Get transferring money from national employees

10. Firing foreign employees

\section{Change law}

12. Get expected return in cash up to return estimation
Lease buildings, lands, transport or producing machines from local resources or international resources

Nonprofit committees. It returns limits by religion condition to distribute and to collect. It must be bought by rich people as result to religion reasons and must be given to poor people to cover necessary needs.

National workers in the world

Foreign employees numbers

Law which may include Tax law, Insurance companies' law and financial papers dealing law. Ex: changing retire age from 60 to 65 to keep social insurance saving up to government need.

Government expected tax, Aids, and investing government gets tax from insurance companies

It keep cash liquidity to be use in other needs it courage lease market

It is way to reduce general budget expenses if it has been given to suitable association

It reduces general budget expenses and it can be way to get revenue. they can be courage to save in local banks which support country portfolio of currencies or to finance financial markets by baying shares or to investing in direct investment in order to reduce import or to help their families.

It is way to avoid transfer money from country and to depend on local citizens' work.

It helps to reduce government liabilities as result

Increase returns at present time
Customers loose there insurance installments if risk not happen.

Government avoid its expenses partly because not all citizen are rich to buy this insurance

It may face increasing of market lease installment cost. It may not find financer as huge of financing capital. It keeps government ownership limit. It needs special conditions to organize the contract and leasing companies.

Loosing trust may lead to religion war also it may be used in bad way as watering money or against government

Need suitable way to get trust with government.

Some of them think government was unfair to deal with them.

This must not cover experiences or problems with international relationship

The problem is leading to complex environment which may lead to conflict.

Decrease returns at future time. Some Items as Aids may not be gotten in future. 


\section{Conclusion}

Deficit dealing can be classified to three types which are to get in self sufficient or surrender to economic equilibrium law or delay problems. Success of any solution must be suitable to country environment limits and must have suitable conditions to success also risk is increasing by delay problems if it increases by time to affect suddenly on country. As result to study General budget deficit financing model can be build in third world country with limits. Tables in this search can help. It declared deficit reasons and explained about 19 ways of financing budget with comparing in order to show choices.

\section{Recommendation}

Searcher recommended finding suitable model for country environment which shows solutions fairly and its affection in order to apply suitable conditions as rule of success. This search tables can help. There must be experts have experiences of country environment and solution condition to success. Available model and available experts are standard of choosing suitable solution but conditions is rule to make this solution to apply practically and control also there are limits to avoid ignorance. The standard is to get trust between citizens, government and companies to cover their needs fairly.

\section{References}

Ahmad, M. (2003). Analyses study about general budget in Jordan up to economic correctly policy. Economic Horizons journal, U.A.E, 24(94), 94-97.

Benjamine, L., Andrew, P. L., \& Randall, W. (2011). Information and Liquidity. Journal of Money, 43(7), 356.

Giammario, I. (2010). International Competition and U.S. R\&D Subside: A Quantitative welfare Analysis, International Economic Review, Economic Department of University of Pennsylvania and the Osaka University Institute of Social and Economic Research Association, 51(4), 1152.

Hendrik Van den Berg. (2001). Economic growth and development- an analysis of our greatest economic achievements and our most exciting challenges (p. 448). U.S.A: McGraw-hill Irwin.

Jamal, A. R. (2011). An application of the investment model for assessing quality costs for higher education providers in Arab world, the first international Arab conference on quality assurance in higher education (pp. 1126 and 1131). Zarqa University, Jordan.

Jean, P. D., Thomas, M., Jean, C. R., \& Stephane, V. (2011). The American finance Association Free cash flow, Issuance Costs and Stock Prices. Journal of Finance, 66(5), 1533.

Makin, A. J. (2002). International macroeconomics (pp. 91, 94 and 107). UK: Pearson education limited.

Manmohan, S. (2014). Manmohan Singh knows very little of the Indian economy, India.

Ministry of planning. (1994). Plan for economic and social development 1993-1997, Jordan, p. 111.

Pedro, S. A., \& Erwan, Q. (2010). Limited Enforcement, Financial Intermediation, and Economic development: A Quantitative Assessment. International Economic Review, 51(3), 
785. http://dx.doi.org/10.1111/j.1468-2354.2010.00601.x

Peter, C., \& Jan, E. E. (2005). Using Six Sigma to improve the Finance Function, Strategic Finance, p. 28.

Peter, S. R., \& Sylvia, C. H. (2010). Bank management and Financial Services (p. 381). U.S.A: McGraw-Hill.

Suresh, C., \& David, L. (2011). Developments in Public Sector Performance Measurement: A Project on Producing Return on Investment Metrics for Law Enforcement. Financial Accountability and Management in Government, Public Services and Charities, Black Publishing Ltd., 27(4), U.S.A

Vincent, R. (2009). The politics of higher education in the Middle East: problems and prospects, Middle East brief, Crown center for Middle East studies, Brandies University, 36, 6.

Zubire, H. (2008). Islamic Banks: Profit sharing, equity, leverage lure and credit control, Munchi Personal RePEe Archieve paper no 11737 p. 29. http://mpra.ub.uni-muenchen.de.

\section{Copyright Disclaimer}

Copyright reserved by the author(s).

This article is an open-access article distributed under the terms and conditions of the Creative Commons Attribution license (http://creativecommons.org/licenses/by/3.0/). 